\title{
Historical Materials Wanted
}

The Iowa State Department of History and Archives is engaged in preserving the story of Iowa. In achieving this high purpose a major objective is the gathering of historical source material-the substance from which history is written. The department solicits the active aid of Iowa citizens in gathering such materials as the following:

DIARIES, letters, account books and similar contemporary records of the pioneer period.

BIOGRAPHICAL ACCOUNTS of pioneers and of persons prominently identified with any phase or period of the state's development.

MANUSCRIPTS AND PRINTED ARTICLES on the history of towns, counties and sections of the state, and on the history of Iowa industries and institutions.

REPORTS, YEARBOOKS AND PUBLICATIONS of Iowa churches, professional and labor organizations, clubs, societies, and similar educational, cultural and fraternal institutions.

HISTORICAL ACCOUNTS and summary statements of banks, industrial plants, and business organizations.

PHOTOGRAPHS of Iowa pioneers and prominent men and women of every period; and pictures of towns, mines, mills, transportation agencies, etc.

BOOKS AND PAMPHLETS pertaining to Iowa and related history of the Mississippi Valley.

IOWA NEWSPAPERS, magazines, maps and prints.

PIONEER RELICS, historical paintings, mementos of historic events and distinguished Iowa persons, and other items suitable and desirable for exhibition in the State Museum.

INDIAN ARTIFACTS and handiwork.

All contributions will be suitably acknowledged and preserved as property of the state. Donors will merit the gratitude of present and future citizens of Iowa. The State Historical Building with its treasures, is one of the finest institutions of its kind. It belongs to the people of Iowa, and deserves their continued support and cooperation to acquire and maintain the sources of our heritage, a never-ending responsibility. 
Copyright of Annals of Iowa is the property of State of Iowa, by \& through the State Historical Society of Iowa and its content may not be copied or emailed to multiple sites or posted to a listserv without the copyright holder's express written permission. However, users may print, download, or email articles for individual use. 